\title{
Relationship of School Environment and English Language Learning at Government Schools
}

\author{
Muhammad Arfan Lodhi ${ }^{1}$, Abdul Hye Sahar ${ }^{2}$, Numra Qayyum ${ }^{3}$, Samreen Iqbal ${ }^{4} \&$ Huma Shareef ${ }^{5}$ \\ ${ }^{1}$ Higher Education Department Collegiate Wing, Punjab, Pakistan \\ ${ }^{2}$ DM Inspection, Punjab Daanish Schools Authority, Lahore, Pakistan \\ ${ }^{3}$ Khawaja Fareed University of Engineering and IT, Rahim Yar Khan, Pakistan \\ ${ }^{4}$ Center of Excellence, Daanish schools Rojhan, Pakistan \\ ${ }^{5}$ NCBA\&E University Lahore, Pakistan \\ Correspondence: Muhammad Arfan Lodhi, Higher Education Department Collegiate Wing, Punjab, Pakistan. \\ Tel: 92-345-726-6968. E-mail: samaritan_as@hotmail.com
}

Received: December 23, 2018 Accepted: January 15, 2019 Online Published: April 28, 2019

doi:10.5539/par.v8n1p1 URL: http://dx.doi.org/10.5539/par.v8n1p1

\begin{abstract}
Academic success of language learners is not only determined by their level of intelligence but it is also associated with the learning environment provided to them. The current study is an attempt to investigate the factors which affect learning environment of English language learners at government schools. In this context a survey based research design was selected by following quantitative methodology. Sample was drawn from the population parameter of government schools. The students were selected randomly whereas teachers and head teachers were selected by using convenient sampling technique. A questionnaire was developed, validated and administered to know the perspectives of the selected respondents. Findings of the study revealed that suitable school environment provides significant contributions to ESL learners' performance and accomplishment. The study also found that student-teacher and teacher-parent relationship promote and strengthen language learning capacity of ESL learners. It is highly recommended to develop such school environment which is conducive to English language learning; as environmental factors at school are as important as pedagogical interventions of ESL teachers.
\end{abstract}

Keywords: school environment, academic achievement, English language learning (ELL), state-run schools

\section{Introduction}

The current study was conducted to investigate the impact of school environmental factors on the performance of English language learners (ELL). The investigation was carried out to establish the relationship of language learning and school facilities. It is mostly observed that environment has positive or negative effects on human beings. The facilities like school building, classrooms, availability of teachers according to the number of students, and other basic requirements needed for teaching and learning have direct impact on students' performance (Sirin, 2005). The study also cast insight on English language learning mechanisms and teaching procedures in Pakistan. Injustice done in English classrooms on account of the antediluvian methods directed teachers to teach English as a subject-centered discipline. It appeals for a thorough overhaul and recommends a dire need to introduce the concept of skill-oriented discipline. This relatively innovative method withstands teaching of English with examples from real life as English language teaching is far more practical than merely slogging at grammar or cramming vocabulary for the sake of learning it (Canagaraj, 1999). The role on environment is rated central and important in creating skill based student centered classrooms. The overall learning environment includes but not focused only to classroom environment, school environment, parents' involvement, societal concerns, teaching atmosphere and social milieu.

\subsection{Background of the Study}

Education is the continuous process of learning from experience while removing unwanted experiments and continuing with the wanted experiments. Moreover, education is the developmental process of such characteristics among the students which enable them to control their environment (LeClair, 2002). Environment 
has strong effect on the development and growth of human beings right from the mother womb. Educational process is nurtured in physical, social, cultural and psychological environment. The interrelatedness of the societal surroundings and the person provides a lively stimulus in the developmental process of a child. Amongst other components, the societal natural world communicates environment that functions as indispensable origin for the child's shaping of his/her own motivations and attitudes (Davis-Kean, 2005; Baumgardener, 2006). Bronfenbrenner (1990), in his Ecological Systems Theory mentioned and stressed upon the elements of the social environment that indirectly develop and build child's character and intensify the positive influence on his/her learning.

Ajzen (1988) describes three types of attitudes which are cognitive, effective and behavioral. The conception of attitude invariably rotates around person's environment, for example objects, people and establishments like schools, colleges and universities. Dörnyei \& Schmidt (2001) define motivation as the direction and magnitude of human behavior and a person's environment influence his motivation and also directs him to select and achieve his goals. Moreover, many other research studies (i.e. Rodney, 2006; LeClair, 2002) found that learner's own family and peers, the blood relatives, school where he takes his lessons, neighbors with whom he mingles for various purposes, social media, the place where his parents work, society, acculturation, history, economic system and practices of law; all influence the learner's achievements. Various research studies were conducted to check the performance of students in old building and new buildings of schools. The studies found that significant number of students performed better in new building then students in old building (Sirin, 2005). The role of environment becomes more crucial in case of learning second or foreign languages. English proficiency skills can be acquired and utilized well in a learning friendly environment. On the whole it can be concluded that school environment plays a significant role in the performance of the students and their language achievement.

\subsection{Statement of the Problem}

The absence of suitable environment makes it difficult for the learners of a foreign language to learn the language easily and comfortably. A dire need is felt to make the school environment suitable for the adult learners to learn any native or foreign language. The problem revolves around the three identified elements that are congenial school environment, school stake holders (students, teachers, and head teachers), and difficulties faced by these stake holders to make the school environment more suitable for the language learners (Samdal, et al 1998). State-run schools in Pakistan faced plight situations in early 90s. However, the situation is being changed rapidly for last two decades where concerned authorities shifted their attention to improve teaching learning conditions which could compete with the global challenges. Digital literacy and computer mediated technology have made school environment learner friendly. However, the school reforming and revolution plan is much slower than the need and expectations. English being the official language of the country for many decades is now enjoying the status of second language in Pakistan. This study investigated the role and need of school environment on the healthy and productive learning of ELLs. So, it attempted to identify the important factors that are necessary for establishing effective language learning environment at schools.

\subsection{Research Questions}

1) What role can environment play in the effective learning of English language at government schools?

2) What is the importance of English teachers in developing congenial language learning environment?

3) What kind of cooperation can be extended by the head teachers to provide language learning facilities?

4) What type of factors can play significant role in developing good English language learning environment at school?

\section{Literature Review}

A proper and adequate environment is necessary for the productive learning and grooming of the students. The environment given to them at home and at school should provide them the necessary stimulus for learning experience (Putnam, et al, 2009). It is necessary that school environment arise curiosity among the students through curriculum, teaching techniques and relationship because students have to spend their most of their study time in school.

\subsection{Environmental Factors Affecting Students' Learning}

It is mostly observed that students learn more when a suitable social environment is provided to them in school. The school is the place of incredible importance in education. The learning environment is directly proportional to the language achievements of learners. Better school environment not only improves their learning but also helps in lessening the drop-out of the students (Battin, et al, 2000). 
Classroom is a place where teachers transfer and students acquire knowledge in order to fulfill the academic needs and achieve learning outcomes. Iipinge (2013) conducted a comparative study in order to check the effect of indoor environment on the quality of occupant's perception of performance. She found that poor indoor environment of the classroom affect students' performance badly. Teachers use different strategies which are useful for the transfer of information. Therefore, it is necessary that classroom should be properly designed with proper air and lighting conditions. Rooms should be airy and spacious enough to accommodate all students. Furthermore, classrooms must be equipped with audio visual aids, learning kits, and language related stuff. A good language classroom must be looked like a language laboratory similar to computer, biology, chemistry and physics laboratories at school.

Facilities related to infrastructure mean those facilities which were provided to the students in the vicinities of school building. A study conducted by Fisher (2001) shows that there is positive correlation between the school infrastructure and students learning outcomes along with their behavior changes. It further shows that school infrastructure has positive impact on the academic achievements and behavior modifications of the students. The facilities related to the infrastructure include:

\section{Infrastructural School Environment Facilities}

- Classrooms

- Library

- A multi-purpose room with a stage and folding seats (auditorium)

- Science Lab-Cum-Lecture Room

- Craft Room

- Art Room

- Home Economics Lab

-Lecture Room for co-educational or girls school

- Music Room

-Staff Room

-Principal's Room

- School Office

-Museum

- Language Labs

-Dramatic Theaters

Figure 1. Infrastructural school environment facilities

\subsection{Pakistani School Environments}

In majority of the Pakistani schools non-material factors constrain healthy learning process. Professional leadership and pupils rights are also included in the factors that influence students learning. These factors are very essential in educational institutes. Majority of the schools of Pakistan face tremendous diversity of language, culture, traditions and ethnicity (Baumgardener, 2006). Though, the situation is being changed rapidly towards the betterment of education and educational infrastructure. However, many schools still lack basic resources like buildings, furniture, drinking water, instructional materials, and qualified teachers. Due to rapid increase in population, number of schools could not be increased in the country. Environment of schools play an important role not only in the academic development of the students but influence their personality as well. Therefore, it is necessary that such environment should be provided where they can get the opportunity to learn quickly and groom well (Horwitz, 2000). Most of the schools are multilingual in the country where English language over dominates the country's national language 'Urdu' and many other regional and local languages.

Government schools lack basic facilities including school building, number of classrooms and availability of teacher according to the number of students. Although some schools have proper school buildings, science labs, classrooms, computer labs and playgrounds but these schools are so much populated that students never get proper opportunity to flourish. Due to overcrowded classrooms it becomes difficult for teachers to treat each student properly and equally (lipinge, 2013). Although some schools have playgrounds but students hardly get the opportunity to play in these grounds. Sports and academic facilities are also not adequate for the students. It is also reality that government is injecting financial aids in the deadly veins of school system, but it is much less 
than the dire need. Private schools in Pakistan are equipped with basic and advanced facilities like having vast and decorated class rooms, qualified and experienced teachers, play grounds, kids room and science labs. Sports and games are given more importance in this school. These schools give more importance to the personality grooming of the students; they are famous for their resources, better environment, facilities, management, attractive and qualified staff etc. Discipline is given more importance therefore it has greater impact on students personality. Students also learn cooperation, coordination and communication skills from co-curriculum activities. So, in comparison environment of private schools is more appeasing, conducive and friendly for language learners as compared to environment of government schools.

The population parameter selected for this study was Daanish Schools. Danish schools system is relatively new project introduced by the Punjab government in 2010 for poor and needy peoples. These schools aimed at facilitating the poor and deprived students who cannot afford fees of private schools. At present, 27 schools are working and providing well-structured schools equipped with airy, neat, clean, well decorated classroom, computer labs, science labs and qualified and experienced teachers. Moreover, these schools are providing such atmosphere which is favorable for English language learning. Students here are encouraged to communicate in English language with their teachers and fellows.

\section{Research Methodology}

\subsection{Research Design}

Research design is given much importance in methodological framework of any study as it works as the blueprint for the study (Blaxter, 2010). Research design helps the researcher to follow a proper road map in order to achieve research objectives. The current study was descriptive in nature and survey based research framework was adopted to collect data. Researchers adopted quantitative methodology to undergo the operational phase and attempted to discover reality following positivist ontology.

\subsection{Population and Sampling}

The population parameter was the government schools of southern Punjab (an underprivileged area of Punjab province, Pakistan), the students, teachers and the head teachers. The accessible population was taken from 20 high schools including 10 male and 10 female schools. 20 head teachers and 20 English teachers of these schools were selected by using convenient sampling technique. Moreover, 200 students were selected by using simple random sampling technique from the selected male and female schools.

\subsection{Research Instrument}

A questionnaire was used to collect data from students, teachers and head teachers about the effect of school environment on the academic performance of the students. This questionnaire consisted of 11 different components. Each component consisted of different statements and five point Likert like scale was given to the participants to scale their responses. First, third, fourth, sixth, ninth components consisted of 'always' to 'never' scale. Whereas, component second, fifth, tenth, twelfth was consist of 'yes, all the time' to 'no response'. Furthermore, seventh, thirteenth component was consist of 'strongly agree' to strongly disagree' scale. Moreover, eighth and eleventh component was based on 'maximum' to 'minimum' scale. Details of the questionnaire components are given below:

First section deals with the statements about the curriculum and educational material. This section consists of five statements in order to know the perspective of all the three stakeholders. The scale used in this section was consisted upon five point Likert type scale from 'always' to 'never'. In second section eight statements were used to collect data about the school board, their duties, responsibilities and their performance. This section used the scale of five points Likert type including: A. yes, all the time, B. yes, most of the time, C. No, not really, D. No, never, E. No response. Third section was based on seven statements regarding the teachers' capacities and abilities. All the three stake holders were asked to share their perspective about lesson plans, classroom activities, and encouragements by the teachers towards their students, asking questions and negative communication in the classroom. The responses used to know their perspective was based on Likert type scale including: A. always, B. often, C. sometimes, D. seldom, E. never. Fourth section was about students' participation. Three statements were the part of this section which was asked to collect their perspective about students' participation in their academics and their ability to learn, their way of expressing their views and their response rate towards school activities. Fifth section is based on four statements related to the learning environment of the schools and classrooms. Availability of sources, the importance given to the lesson plans and activities conducted in the classrooms are also discussed. This section takes the scale of five points Likert type including: A. yes, all the time, B. yes, most of the time, C. No, not really, D. No, never, E. No response. Section six was about parents' 
involvement. Four statements were the part of this section which was asked to collect their perspective about parents' involvement in school activities and its impact on student's achievements. Furthermore, seven statements were included section 7 which was asked to collect perspectives about the availability of the resources in the school related to learners' needs of English language learning. It includes statements about the availability of language labs, English movies, books, CDs or maps for English language teaching. The scale of section 8 is based upon Likert type like: A. Maximum, B. moderate, C. mild, D. meek, E. minimum. Next section was about school policy which consisted of two statements about the school policy towards the code of conduct not only for teachers but also for the students. Next sections were about the provisions of friendly and supportive atmosphere, Students' power of expression, communication skills and facilities regarding English language learning environment.

\subsection{Validity and Reliability of Questionnaire}

Validity of data collection tools means that the finding of the study is the true representative of the phenomenon that they are claiming to measure. On the other hand, reliability in the research means to what extent the assessment is consistent. It refers to the inter consistency of the items. The questionnaire was developed and refined in the lights of recommendations of couple of professional colleagues. Statistical validity and reliability was obtained by gaining the acceptable alpha level in cronbach testing. The instrument was further refined in pilot testing phase and was made ready for administration.

\subsection{Research Procedure}

Research procedure includes the whole set of activities including planning and the process of organization. Research is a systematic procedure of problem analysis, model building and fact finding for the purpose of the making important decisions. Researchers framed relevant research design in order to find the answers of the research questions. After the selection of appropriate research design next step was to collect appropriate sample from the whole population. Researchers selected suitable sample from the whole population by using Sekaran (2000) taxonomy. Data collection tools were pilot tested before they were administered to the participants of the study. Moreover, informed consent was taken from the respondents of the study. The collected data was tabulated and processed in SPSS for analysis purpose, which was further explained through tabular and narrative interpretation. At the end of the study, conclusion was drawn in the lights of findings obtained from statistical and logical interpretations.

\section{Data Analysis}

The data collected from questionnaire revealed opinions of students, teachers and head teachers related to different factors which affect learning mechanism of ESL learners at school. The results obtained from questionnaires are discussed as under:

Table 1. Curriculum and educational materials

\begin{tabular}{lccc}
\hline \multicolumn{1}{c}{ Statement } & Students & Head teacher & Teacher \\
\hline The English curriculum meets students' needs in practical ways. & 4.43 & 3.95 & 3.95 \\
Students have acquaintance with enrichment material and other resources. & 3.85 & 4.00 & 4.0 \\
The institution is helpful in providing resource material for teaching. & 2.13 & 4.2 & 1.35 \\
Teachers are facilitated with computer assisted language teaching in school. & 3.48 & 3.8 & 3.55 \\
English teachers and students' achievements are acknowledged properly. & 3.25 & 4.0 & 3.65 \\
\hline
\end{tabular}

Mean score coding criteria: Always $=5$, Often $=4$, Sometime $=3$, Seldom $=2$, Never $=1$

Table 1 reflects head teachers, teachers and learners' perspective about school environment. The statistics collected from the three questionnaires revealed that head teacher favors the statement that they always facilitate students and teachers with the material they need. However, data collected from teachers and students were contradictory which shows that head teacher seldom facilitate them with the supplies as the calculated mean score of teachers was 1.35. Moreover, learners mean score 2.13 shows that school sometime facilitate them with the supplies. Overall data shows that supply of curriculum and educational material is very satisfactory. 
Table 2. School administration role

\begin{tabular}{lccc}
\hline \multicolumn{1}{c}{ Statement } & Students & Head teacher & Teacher \\
\hline Teaching staff is fully aware of the needs and demands of English learners. & 2.5 & 4.4 & 3.65 \\
Teacher-student ratio in English class is according to international standards. & 3.15 & 4.45 & 3.4 \\
School heads / authorities fulfill English teachers' teaching demands. & 3.98 & 4.5 & 3.8 \\
Teachers are given appreciation from school authorities. & 3.65 & 4.65 & 3.85 \\
There is proper monitoring and assessment system of English teachers. & 3.85 & 4.05 & 3.95 \\
Teachers share their teaching and learning experiences among one another. & 3.5 & 4.15 & 3.9 \\
School offers professional development workshops for English teachers. & 2.9 & 3.75 & 3.1 \\
Time table adequately fulfill ELLs needs and demands. & 4.05 & 4.15 & 3.55 \\
\hline
\end{tabular}

Mean score coding criteria: Yes, all the time $=5$, Yes, most of the time $=4$, No, not really $=3$, No, never $=2$, No response $=1$

Table 2 shows head teacher, teachers and learners' perspective about school environment. The statistics collected from the three questionnaires revealed that head teachers comments were more in favor of school board as their mean score was 4.65. Moreover, mostly students were not in favor of the statement that the principal and the teachers are acquainted with the guidelines that support the child's needs as the mean score was 2.50. However, teachers' comments were in favor of these statements that principal regularly monitors the work of the teachers and gives needed support in positive manner most of the time; the calculated mean score about this perspective was 3.95.

Table 3. Teaching capacity

\begin{tabular}{lccc}
\hline \multicolumn{1}{c}{ Statement } & Students & Head teacher & Teacher \\
\hline English teachers devise and revise lesson plans regularly. & 3.38 & 3.55 & 4.86 \\
Teachers use student-centered approach in language classroom. & 4.83 & 3.4 & 3.6 \\
Teachers encourage cooperative and collaborative learning in class. & 3.8 & 3.35 & 3.85 \\
English teachers are flexible in using different teaching techniques. & 3.55 & 2.44 & 3.8 \\
Students are encouraged to develop decision making habits in school. & 3.35 & 4.0 & 3.85 \\
ELLs classroom participation is encouraged by their teachers. & 3.7 & 3.35 & 4.0 \\
Teachers are discouraged to scold or abuse students in the school. & 3.05 & 3.25 & 3.15 \\
\hline
\end{tabular}

Mean score coding criteria: Always $=5$, Often $=4$, Sometime $=3$, Seldom $=2$, Never $=1$

The data collected from the questionnaires revealed students stated that their teachers are trained to teach them in student centered classroom; the mean score shows 4.83. But, head teachers stated that teachers never uses methodologies which were suitable for their age as their mean score was calculated 2.44. However, teachers stated that they always encourage their students to think and make decisions independently as the mean score was 3.85. Data shows that teachers regularly prepare lesson plans and encourage students' participation adequately.

Table 4. Students' participation

\begin{tabular}{lccc}
\hline \multicolumn{1}{c}{ Statement } & Students & Head teacher & Teacher \\
\hline Students focus to acquire language and life skills in school. & 3.98 & 3.4 & 4.0 \\
ELLs participate in sequential art and co-curricular activities in school. & 3.65 & 3.85 & 3.9 \\
Students participate in curricular and extracurricular activities with interest. & 3.68 & 3.8 & 4.1 \\
\hline
\end{tabular}

Mean score coding criteria: Always $=5$, Often $=4$, Sometime $=3$, Seldom $=2$, Never $=1$ 
Table 4 shows statistics collected from the questionnaires and revealed that head teachers always encourage their students to take part in school activities according to their interests as the mean score was 3.85. However, students stated that they were sometime able to learn basic skills whereas teachers often encourage them to express their thoughts and feelings through art and other activities as the mean score was 3.65. In contrast to this a large number of teachers stated that all students, according to their abilities, learn the basics i.e. skills for writing, reading and necessary life skills as the mean score was 4 .

Table 5. Learning environment

\begin{tabular}{lccc}
\hline \multicolumn{1}{c}{ Statement } & Students & Head teacher & Teacher \\
\hline Learning environment is stable, dynamic and pleasant in school. & 3.45 & 4.65 & 3.45 \\
School has established library and learning corners. & 3.6 & 4.35 & 3.4 \\
Teaching strategies and lesson planning are conducive to learning English. & 3.01 & 4.25 & 3.65 \\
Students are made aware of the outcomes of English teaching strategies. & 3.46 & 4.4 & 3.8 \\
\hline Mean score coding criteria: Yes, definitely=5, Yes, probably=4, No, not really=3, Not sure=2, No response=1
\end{tabular}

Table 5 describes head teachers, teachers and learners' perspective about school environment. It is evident that head teachers commented that they absolutely facilitate dynamic and active learning environment for all the students as the mean score was 4.65; but students mean score 3.45 expressed that they were not facilitated with dynamic learning environment all the time. However, some of the teachers stated that the materials and lesson plans are prepared in order to help students as the means score of this related statement is 3.8 .

Table 6: Parents' involvement

\begin{tabular}{lccc}
\hline \multicolumn{1}{c}{ Statement } & Students & Head teacher & Teacher \\
\hline Parents visit school to get awareness about their children performance. & 3.34 & 3.6 & 3.35 \\
Students' parents are included in the school management committee. & 2.75 & 4.1 & 2.85 \\
The authorities involve parents in child and school improvement plans. & 3.39 & 4.2 & 2.65 \\
Parents are encouraged to participate in parent meetings and school events. & 2.91 & 4.6 & 3.45 \\
\hline
\end{tabular}

Mean score coding criteria: Always $=5$, Often $=4$, Sometime $=3$, Seldom $=2$, Never $=1$

Table 6 compares head teachers, teachers and students' perspective about parents' involvements. Data demonstrates that school authorities consider parents' involvement integral in school improvement and learner improvement plans. On the other hand, students and teachers stated that parents were sometime involved in school related activities as the mean scores were 2.75 and 2.85. It is obvious from the analysis that school heads are very curious about parental involvement in school affairs. However, students opined that their parents are mildly interested in their school related issues.

Table 7. Availability of resources

\begin{tabular}{lccc}
\hline \multicolumn{1}{c}{ Statement } & Students & Head teacher & Teacher \\
\hline English literature books available at school library & 3.79 & 3.9 & 4.35 \\
Availability of language labs at schools & 2.95 & 3.2 & 2.25 \\
English movies for language teaching & 2.0 & 2.25 & 2.15 \\
English grammar books & 3.75 & 4.1 & 4.3 \\
C.Ds of spoken language & 1.95 & 2.35 & 1.3 \\
World atlas /Maps or geography charts & 2.8 & 3.7 & 2.8 \\
Dictionaries mono & 3.64 & 3.2 & 3.15 \\
\hline
\end{tabular}

Mean score coding criteria: Strongly Agree $=5$, Agree $=4$, Not Sure=3, Disagree $=2$, Strongly Disagree $=1$ 
Table 7 compares head teachers, teachers and learners' perspective about availability of resources at school. The data revealed that head teachers were strongly agreed with the statements that English literature books, grammar books, world atlas/ maps or geography charts, and dictionaries are available at school library as the mean scores were 3.9, 4.1, 3.7 and 3.2. Whereas some of the head teachers were just agreed with the statement that school has language labs and English movies are shown for language teaching purpose; the mean scores were 3.2 and 2.25 respectively. Data further reveals that students and teacher were also agreed with the opinions given by head teachers in this regard.

Table 8. Availability of resources for students use

\begin{tabular}{lccc}
\hline \multicolumn{1}{c}{ Statement } & Students & Head teacher & Teacher \\
\hline English literature books available at school library & 2.68 & 3.5 & 2.9 \\
Availability of language labs at schools & 1.2 & 1.15 & 1.5 \\
English movies for language teaching & 2.95 & 1.0 & 2.7 \\
English grammar books & 2.38 & 4.0 & 1.2 \\
C.Ds of spoken language & 1.58 & 3.75 & 1.3 \\
World atlas /Maps or geography chats & 3.2 & 4.9 & 3.2 \\
Dictionaries monolingual & 3.2 & 3.45 & 3.3 \\
\hline
\end{tabular}

Mean score coding criteria: Maximum=5, Moderate $=4$, Mild =3, Meek $=2$, Minimum=1

The above table shows the extent of usage of resources at school. The statistics revealed that head teachers stated that English literature books, grammar books, world atlas/ maps or geography charts. Monolingual dictionaries are available at maximum level for the students at school library. Whereas some of the head teachers stated that language labs and English movies for language teaching are available at minimum level. However, students and teacher comments were different from head teachers and maximum number of students belongs to the category of 'meek' to 'minimal' and teachers belong to the category of 'mild' to 'meek'. It is evident from the results that students and teachers randomly use resources for their learning and teaching purposes.

Table 9. School policy

\begin{tabular}{cccc}
\hline Statement & Students & Head teacher & Teacher \\
\hline School has fair policy for teachers' assessment and reward criteria. & 3.03 & 4.1 & 2.95 \\
School maintains discipline through documented code of conduct. & 3.55 & 4.0 & 4.3 \\
\hline
\end{tabular}

Mean score coding criteria: Always $=5$, Often $=4$, Sometime $=3$, Seldom $=2$, Never $=1$

Table 9 compares the opinions of head teachers, teachers and learners about school policy. The data collected from the questionnaires revealed that head teachers stated that policy for teachers' performance is always fair and transparent at school as the mean score was 4.1; however, teachers' opinions contrast to head teachers' responses in this regard as their calculated mean was 2.95. Whereas students remain neutral about the statement as the mean score was 3.03. On the other hand, majority of members belong to the category of 'sometime' to 'often' about the statement that the school has a code of conduct for the teachers. 
Table 10. Providing a friendly and supportive atmosphere

\begin{tabular}{lccc}
\hline \multicolumn{1}{c}{ Statement } & Students & Head teacher & Teacher \\
\hline Students are trained to bear caring and supportive attitude for fellows. & 4.30 & 4.25 & 4.25 \\
Students participate in English speech and debate competitions. & 4.50 & 4.35 & 4.25 \\
Teachers always facilitate students who face anxiety in the language class. & 4.43 & 4.15 & 4.35 \\
Students are motivated through appreciation and awards. & 4.38 & 4.10 & 4.40 \\
School environment brings confidence among language learners. & 4.40 & 3.95 & 4.45 \\
\hline
\end{tabular}

Mean score coding criteria: Yes, all the time $=5$, Yes, most of the time $=4$, No, not really $=3$, No, never $=2$, No response $=1$

Table 10 describes head teachers, teachers and learners' perspective about providing friendly and supportive atmosphere. The statistics revealed that teachers and students comments that school all the time provides them with friendly and supportive atmosphere as the majority of rating about the statements were 4.25. Data also shows that according to head teachers, school most of the time motivates and appreciates teachers as the mean score was 4.1. Data also shows that school environment is conducive to English language learning and it provides confidence and trust to students to learn and grow.

Table 11. Expression of views

\begin{tabular}{lccc}
\hline \multicolumn{1}{c}{ Statement } & Students & Head teacher & Teacher \\
\hline Students express their views in English with interest and confidence. & 3.75 & 4.1 & 3.65 \\
School arranges events that promote English proficiency skills. & 3.83 & 4.2 & 4.25 \\
Students benefit from events and polish their writing and speaking skills. & 2.68 & 3.9 & 2.85 \\
\hline
\end{tabular}

Mean score coding criteria: Maximum $=5$, Moderate $=4$, Mild $=3$, Meek $=2$, Minimum $=1$

Table 11 demonstrates role of school in motivating learners to express their ideas and opinions in English language. According to head teachers, students get maximum benefits from the school events arranged for them. However teachers and students opined about same phenomenon differently. According to students and teachers, their school arranges events and programs that facilitate language learning. However, they were of the view that students could not get maximum language benefits from such events.

Table 12. Participation of parents in support of language learning and character building

\begin{tabular}{lccc}
\hline \multicolumn{1}{c}{ Statement } & Students & Head teacher & Teacher \\
\hline Parents are advised to help students in building their English proficiency. & 3.75 & 3.75 & 3.75 \\
Parents help teachers in sorting out attitudinal problems of their children. & 3.68 & 3.65 & 3.7 \\
School holds continuous parent teacher meetings with English teachers. & 3.33 & 4.2 & 3.35 \\
Teachers assign communicative home tasks to students. & 3.28 & 4.15 & 3.05 \\
Parents are given continuous feedback regarding their child's progress. & 2.03 & 4.3 & 1.5 \\
\hline Mean score coding criteria: Yes, all the time=5, Yes, most of the time=4, No, not really=3, No, never=2, No \\
response=1
\end{tabular}

Table 12 shows head teachers, teachers and learners' perspective about participation of the parents. The data shows that all the three stakeholders stated that parents are made deliberately involved in developing English proficiency skills among their children by using different plans and strategies. Highest mean value 4.2 shows that all the three stakeholders were agreed that all the time parents were involved in students' language education and language improvement. However, the lowest rating 2.03 from students and 1.5 from teacher show that parents rarely receive individual information from school regarding achievements of their children. 
Table 13. Language learning facilities

\begin{tabular}{lccc}
\hline \multicolumn{1}{c}{ Statement } & Students & Head teacher & Teacher \\
\hline Computer is used for English teaching purpose in my school. & 1.33 & 1.35 & 1.4 \\
Audio-visual aids are used for making English language learning easy. & 2.1 & 3.05 & 2.05 \\
English teachers use latest technology in classroom. & 1.55 & 1.9 & 1.95 \\
Teachers also use authentic material for teaching language & 4.05 & 4.15 & 3.3 \\
Teacher provides extensive reading material for teaching English. & 3.23 & 3.95 & 3.95 \\
Teachers discuss local affairs for learning purpose. & 4.18 & 4.3 & 4.05 \\
Teachers discuss global affairs for learning purpose. & 3.98 & 4.55 & 3.7 \\
Teachers also introduce Islamic and world history for language leaning. & 3.98 & 3.55 & 4.1 \\
Economic challenges are discussed for language learning. & 1.7 & 2.7 & 2.0 \\
\hline
\end{tabular}

Mean score coding criteria: Strongly Agree $=5$, Agree $=4$, Not Sure $=3$, Disagree $=2$, Strongly Disagree $=1$

Table 13 mentions head teachers, teachers and learners' perspective about school environment. The statistics collected from the questionnaires revealed that majority of members were 'disagreed' that computer and other technologies were used for English teaching purpose in the school; as the mean scores were 1.3 and 1.5. However, some of them agreed that teachers discuss local, global, Islamic and historical issues for teaching English language as the mean value was 4.55 and 4.18.

\section{Findings and Discussions}

\subsection{What Role can Environment Play in the Effective Learning of English Language at Government Schools?}

According to Byoung-suk (2012), children need safe, healthy and stimulating environment to grow and to learn where they can get better nourishment. It is a general observation that children spend 6 to 8 hours at school. Furthermore, students spend some of the time in the grounds, corridors or yards of the school. Therefore, it is necessary that they should be provided such environment which can groom their hidden skills. This condition needs careful planning and its designing make it possible to achieve objectives like education, health and stewardship. Thus school environment occupies a paramount status in shaping and reshaping the intellectual abilities. Moreover, favorable school environment, having enough learning/teaching facilities makes students more comfortable to learn in comfortable environment, where they can concentrate on their academic, physical and mental growth. The school environment also plays a significant role in the development of the students. The education process occurs in physical, social, cultural and psychological environment of the school. Therefore, it is necessary that school provide a favorable environment where students get enough stimuli for learning English language.

\subsection{What Is the Importance of English Teachers in Developing Congenial Language Learning Environment?}

The environment provided at school has its impact on the academic achievements of the students. Teachers play significant role in maintaining and sustaining a learning friendly environment at school. Moreover, school infrastructure also plays a positive role in motivating students towards language learning. However, the physical structure of the school building and the interactions between teachers and students also influence students' performance. School climate can be a positive influence on the health of the learning environment or a significant barrier to learning. The school environment can affect many areas and people within schools. For example, a positive school climate has been associated with fewer behavioral and emotional problems for students. Therefore, it is believed that positive interpersonal relationship between teachers and students can increase students' achievement behavior improvement. Positive student teacher relationship brings about a positive and supportive school climate. Denial \& Felix (2014) examined the impact of the school environment and peer influence on the students' academic performance. The study assessed school environment factors and peer influence in term of the level of psychological impact they have on learners. Accordingly, they also advocated that role of teachers is the most important factor of school environment and improvement plan, and it determines language learning performance of English language learners.

\subsection{What Kind of Cooperation can Be Extended by the Head Teachers to Provide Language Learning Facilities?}

Eric (2005) discussed the role of the supportive school environment in promoting academic success and postulated that the school environment has broad influence on students' learning and growth, including a 
significant aspect of their social, emotional and ethical development. When students find their school environment supportive and caring, they are less likely to become involved in substance abuse, violence and other problem behavior. The research indicated that supportive schools foster these positive outcomes by promoting students sense of connectedness. These terms are used interchangeably here to refer to students' sense of being in a close, respectful relationship with peers and adult at school. Therefore, building in a school community is a means of fostering academic success. Students who experience their school as a caring community become more motivated, ambiguous and engaged in their learning. In particular, students' active connection with head teachers and their perceptions that head teachers care about them stimulate their effort and engagement in English language class. Another research conducted by Oworye (2011) showed that there is a significant difference between the academic achievement of students in rural and urban secondary schools as measured by senior school certificate examinations. To him, the role of head teachers and geographical location of schools have a significant influence on the academic achievement of students. Data shows that majority of head teachers told that they adopt best measures to develop learning friendly environment in school. However, opinions taken from students and teachers regarding similar factors were very different from head teachers' remarks. According to students and teachers, head teachers should cooperate and support the learning and teaching process at school. Therefore, findings reveal that the head teachers and the teachers should provide a favorable learning environment where students are free to consult them when in need. They should also provide adequate education facilities that can arouse interest in the students and motivate them to work hard. It is believed that a cordial relationship between the head teacher and students create an environment favorable to learning. The head teacher works together with students on how to attain success in academic and personal life. In a good school, every member is important in the decision-making process, and students are usually disciplined and possess positive academic attitude. Findings of this study indicate that head teachers could not arrange language contests, competitions and events on frequent basis; though other school events take place under their control.

\subsection{What Type of Factors can Play Significant Role in Developing Good English Language Learning Environment at School?}

The findings show that school infrastructure, audio visual aids, enrichment material, language lab materials, and relationship among teachers, students and head teachers play significant role in establishing sound and healthy environment for English language learning. The results of this study correlate with the findings of previous studies that weak relationships between teacher-teacher, student-student, and teacher-student have significantly negative effect on students' attitude. Therefore, the teachers should be friendly and supportive to students, head teachers and to school. It is important to note that when healthy teacher-teacher relationship exists in school, it determines learners' academic success, positive attitude, high interest and sound character. Findings reveal that physical environment of school is also an important factor in enhancing English proficiency skills among learners. A research conducted by Sunday (2012) revealed that there is a significant relationship between physical school environment and students' academic performance. The physical facilities, human resources, and the relationship among them determine the physical environment of the school. The result indicated that students with adequate laboratory facilities in physics perform better than those with less or without facilities in school. It was also discovered that poor facilities and inadequate space, as well as the arrangement of items including seats in the classroom, library and laboratory, would affect the organization of learning environment. Favorable school climate gives room for students to work hard and enhance their academic achievement. Orlu (2013) conducted a research among six hundred teachers and students with the aim to find out environmental influence on the academic performance of secondary school students, and concluded that the school environment has a significant influence on academic performance. The findings of the current study also reflect the positive influence of school environment on the learning capacity of language learners.

\section{Conclusion}

Present study suggests that school environment plays a significant role on the academic achievements of the students. Findings obtained from the respondents indicate that school environment influences the achievements of the learners. The data also highlighted that school overall environment, infrastructure, facilities and the modern equipment available at schools have positive impact on the academic achievements of ESL students and enhance their language learning performance. The findings further highlighted that modern facilities such as computer, internet, different laboratories (i.e. physics, chemistry, biology, and English language) and library, when provided to students, make their learning easy and more comfortable.

The factors which influence students' performance and their achievements include appropriate teaching methodology, smart and skilled teachers, favorable learning atmosphere, excellent teacher-student relationship, 
and good school-parent relationship; all these factors facilitate language learning opportunities at school. The findings of current study support the results of previous studies that feeble association between teachers, students and institution affects students' attitude in miscellaneous ways. Basque \& Dore (1998) stated in this context that learning environment ought to implement six functions: inform, communicate, collaborate, produce, scaffold and manage. Therefore, it is necessary that teacher's attitude should be friendly and positive in teaching and learning environment (Sunday, 2012). Moreover, other research studies conducted by Arul, et al. (2012) also supported the findings of this study and revealed that environment provided them in school not only influence their character but also has a significant influence on their academic achievements. In the light of findings obtained from recent study, it is recommended that teachers should understand and appreciate the diverse domestic environment of their students. Moreover, teachers should modify their language teaching methodologies according to the needs of the ELLs. It is suggested for the parents that they should involve actively with school authorities and get feedback about their children education. Lastly, it is also suggested for future researchers to conduct further research on developing healthy learning environment for ELLs at college and university level.

\section{References}

Ajzen, I. (1988). Attitudes, personality, and behavior. Chicago: Dorsey Press.

Arul Laurence, A. S. (2012). School Environment \& Academic Performance of Standard Six Students. Journal of Educational and Industrial Studies in the World, 2(3).

Basque, J., \& Dore, S. W. (1998). Environment and Apparatus hip information. Journal of distance education, $13(1)$.

Battin, S. R., Abbott, R. D., Hill, K. G., Catalano, R. F., \& Hawkins, J. D. (2000). Predictors of early high school dropout: A test of five theories. Journal of Educational Psychology, 92, 568-582. https://doi.org/10.1037/0022-0663.92.3.568

Baumgardener, R. J. (2006). The indigenization of English in Pakistan. In K. Bolton \& B. B.

Blaxter, L. (2010). How to research (4th ed.). Maidenhead: Open University Press.

Bronfenbrenner, U. (1990). Discovering what families do. In Rebuilding the Nest: A New Commitment to the American Family. Family Service America.

Byoung-suk, K. (2012). Landscape Performance Research; School Environment \& Students' Performance. Paper from Landscape Architecture Foundation.

Canagaraj, A. S. (1999). Resisting linguistic imperialism in English teaching. Oxford. Oxford University Press.

Danial, K. K., \& Felix, K. (2014). The Impact of School Environment and Peer Influence on Students' Academic Performance in Vihige County, Kenya. International Journal of Humanities and Social Science, 4(5).

Davis-Kean, P. E. (2005). The influence of parent education and family income on child achievement: The indirect role of parental expectations and the home environment. Journal of Family Psychology, 19, 294-304. https://doi.org/10.1037/0893-3200.19.2.294

Dornyei, Z., \& Schmidt, R. (Eds.). (2001). Motivation and second language Acquisition. Honolulu, HI: University of Hawaii Press.

Eric, S. (2005). The Role of Supportive School Environment in Promoting Success, an Article from Development Studies Centre (DSC); Developing Safe and Healthy Kids, Published in Getting Result, update 5 (chapter3).

Fisher, K. (2001). Building better outcomes: the impact of school infrastructure on student outcomes and behavior. Schooling Issues Digest.

Horwitz, E. H. (2000). Teachers and students, students and teachers: An ever-evolving partnership. The Modern Language Journal, 84(4), 523-535. https://doi.org/10.1111/0026-7902.00085

Iipinge, S. M. (2013). Challenges of large class teaching at the University: Implications for continuous staff development activities. Simon Fraser University, Burnaby, British Columbia, Canada.

LeClair, J. A. (2002). Social status and children's behaviour: Do ecological correlations reflect family level associations? The Canadian Geographer, 46, 325-336. https://doi.org/10.1111/j.1541-0064.2002.tb00754.x

Orlu, C. (2013). Environmental Influence on the Academic Performance of Secondary School Students in Port Harcourt Local Government Area of River State. Journal of Economic and Sustainable Development, 4(12).

Owoeye, J. S. (2011). School Location and Academic Achievement of Secondary School in Ekiti State, Nigeria. 
Journal of Asian Social Science, 7(5). https://doi.org/10.5539/ass.v7n5p170

Putnam, R., McCart, A., Griggs, P., \& Choi, J. H. (2009). Implementation of School-wide Positive Behaviour Support in Urban Settings. In W. Sailor, G. Dunlap, G. Sugai, \& R. Horner (Eds.) Handbook of Positive Behaviour Support (pp. 443-463). New York: Springer. https://doi.org/10.1007/978-0-387-09632-2_19

Rodney H. (2006). Studies in Second Language Acquisition. Cambridge University Press.

Samdal, O., Nutbeam, D., Wold, B., \& Kannas, L. (1998). Achieving health and educational goals through schools: A study of the importance of the school climate and the students' satisfaction with school. Health Education Research, 13, 383-397. https://doi.org/10.1093/her/13.3.383

Sekaran, U., (2000). Research Method for Business (3rd Ed.). New York: John Wiley \& Sons, Inc.

Sirin, S. R. (2005). Socioeconomic status and academic achievement: A meta-analytic review of research. Review of Educational Research, 75, 417-453. https://doi.org/10.3102/00346543075003417

Sunday, A. A. (2012). The Relationship among School Environment, Student Approaches to Learning and Their Academic Achievement in Senior Secondary School in Physics. International Journal of Educational Research \& Technology, 3 .

\section{Copyrights}

Copyright for this article is retained by the author(s), with first publication rights granted to the journal.

This is an open-access article distributed under the terms and conditions of the Creative Commons Attribution license (http://creativecommons.org/licenses/by/4.0/). 